\section{Developing countries boost spread of GM crops}

Planting of genetically modified (GM) crops grew by $9.4 \%$ in 2008 to 125 million hectares worldwide, achieving a total value of US $\$ 7.5$ billion, according to a report published on 11 February by the International Service for the Acquisition of Agri-biotech Applications, a non-profit biotech industry group.

In total, 15 developing countries and 10 industrial countries planted GM crops last year (see chart). The United States, with 62.5 million hectares, planted half of the total, the figures show.

Three countries grew GM crops commercially for the first time, including two in Africa. Egypt opted for biotech maize (corn) and Burkina Faso for cotton. Together with South Africa, which has grown biotech cotton, maize and soya beans since 1998, they bring the continent's total of GM-growing nations to three. Bolivia, 2008's third GM adopter, grew soya beans.

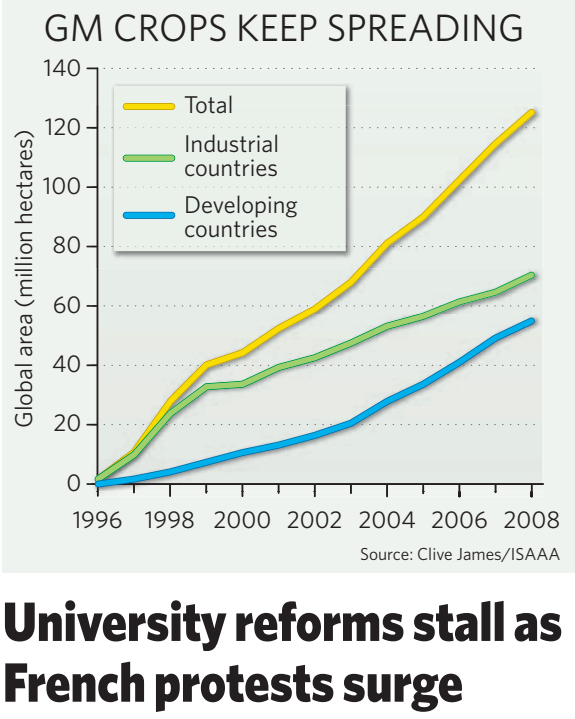

French scientists voted on 12 February to continue a national strike that began on 2 February in protest at proposed government reforms of academic careers (see Nature 457, 640-641; 200 9). Valérie Pécresse, France's science minister, had offered a twomonth mediation to revise the draft decree implementing the changes, but to no avail.

The row gathered momentum with nationwide street demonstrations on 10 February; Paris alone saw as many 40,000 researchers and students turn out to protest.

Researchers have now expanded their demands to include reversing the proposed transformation of the CNRS, Europe's largest basic-science agency, into a research council, and other reforms of the university and research systems.

The government lost further support as university presidents, top scientists and a slew of research bodies called for the reforms to be rethought in closer consultation with the research community. For a longer version of this story, see http://tinyurl.com/a9roy5

\section{Budget crisis drives Harvard to redundancies}

Harvard University will offer voluntary redundancy to 1,600 or so of its non-faculty employees. The offers are to target staff who are 55 years or older and have worked for the university for at least a decade.

The "early retirement program" was unveiled on 11 February and is the latest sign of the budget crisis facing the world's wealthiest university. The university's endowment, which in June 2008 stood at US $\$ 36.9$ billion, shrank by $22 \%$ late last year (see Nature 457, 11-12; 2009). The university estimates that the drop may reach $30 \%$ by the end of its fiscal year in June.

To cope with the crisis, departments have frozen faculty hiring and have begun to draw up contingency plans in case large building projects - including a proposed new science complex - are put on hold.

\section{Safety precautions delay start-up of hadron collider}

The Large Hadron Collider (LHC), the world's most powerful particle accelerator, will see no collisions until late October, more than a year after its planned start date.

Officials from CERN, the LHC's host laboratory near Geneva, Switzerland, had hoped to restart the machine by summer 2009, after it was seriously damaged during power tests last September. But on 9 February CERN announced a further delay, citing additional safety protocols and complex repair schedules as the reasons.

With a short technical stop over Christmas, the LHC will run through to autumn 2010, but it will accelerate its protons to just 5 teraelectronvolts $(\mathrm{TeV})$,

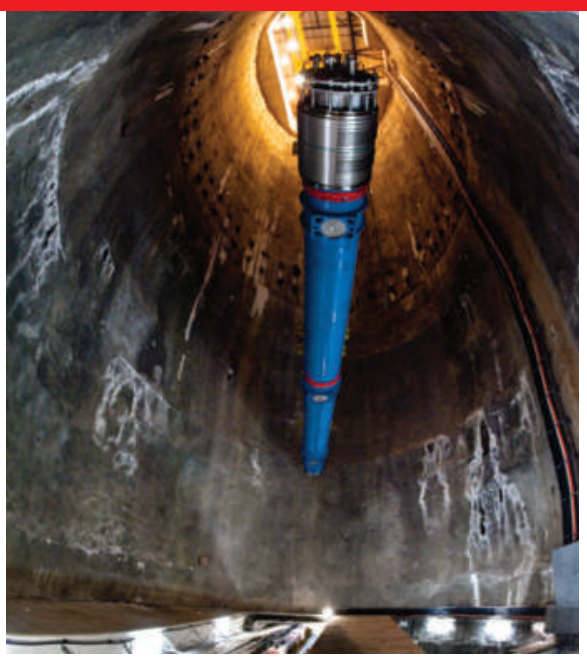

A superconducting magnet is removed at the $\mathrm{LHC}$.

well below its designed $7 \mathrm{TeV}$. Pauline Gagnon, an experimental physicist with ATLAS, one of the LHC's detectors, thinks that at the reduced power "the chances of finding something will be limited", but that the LHC might still see some new physics. For a longer version of this story, see http://tinyurl.com/cy29f5.

\section{GSK backs patent pool for neglected diseases}

Pharmaceutical giant GlaxoSmithKline (GSK) will share the patented knowledge it uses to develop medicines for neglected tropical diseases (NTDs) - including malaria and tuberculosis - with other drugs companies, governments and nongovernmental organizations.

Andrew Witty, GSK's chief executive, proposed the voluntary 'patent pool' in a 12 February speech, and called on other drugs firms to open up access to intellectual property relevant to NTDs.

Starting this year, Witty announced, GSK will also cap its prices for patented medicines in poor countries at $25 \%$ of what it charges in developed countries. It will also reinvest $20 \%$ of the profit it makes from selling medicines in poor nations into health-care infrastructure projects in those countries.

\title{
SOUNDBITES FROM CHICAGO
}

Some insights from this year's meeting of the American Association for the Advancement of Science.

"We are basically looking now at a future climate that is beyond anything we've considered seriously in climate model simulations."

Chris Field co-chair of the Intergovernmental Panel on Climate Change's second working group

"[Cloning a Neanderthal] starting from the DNA extracted from a fossil is and will remain impossible as far as I can see into the future."

Svante Pääbo sequencer of the Neanderthal genome
"If life did happen many times, there could be something like a shadow biosphere that either was, or is, all around us."

Paul Davies Beyond Center, Arizona State University

"[President Obama] sees the value of science not just as a way of keeping those strange members of our society employed who want to go off and do quirky things. ... He is really valuing the product."

James McCarthy AAAS president 